\title{
A Descriptive Study on the Motivation of Bosnian Workers
}

\author{
Muhammed Kürşad Özlen \\ Faculty of Economics and Administrative Sciences, Ishik University/Erbil, Iraq \\ E-mail: kursadozlen@yahoo.com
}

Faruk Hasanspahic

Faculty of Economics, International Burch University

71000, Sarajevo, Bosnia and Herzegovina

E-mail:dj_hapa@hotmail.com

DOI: $10.6007 /$ IJARBSS/v3-i7/20

URL: http://dx.doi.org/10.6007/IJARBSS/v3-i7/20

\begin{abstract}
At one point, motivation is what drives us forward, towards achieving the goals. In every business environment, every employee has its own goal. The managers need to know what drives their employees to perform better, since if the individual performance is raised, the organizational performance increases too. The employer needs to know if his employees reward is money-related, or maybe it is self-satisfaction, feel of empowerment or recognition of his colleagues. What matter is having workers have something to strive for, some force that drives them towards his goal. In this paper we try to explain step by step motivational theories, introduce motivation as concept, and find out antecedents (attitudes towards employees, reward system, supportive organizational culture and employee self-efficacy) and consequences (job satisfaction, involvement, work commitment, loyalty, organizational and individual performance) of employee motivation. We are going to focus mainly on voluntary environment where the circumstances and decision making factors are flexible. The research method conducted was based on survey questionnaire where 300 respondents - workers gave their answer to the research question. The findings mainly provided a neutral agreement level of respondents for the research questions expect the negative amount of attitudes towards employees and positive amount of individual performance in these circumstances. The findings suggested that the respondents of the questionnaire are not motivated both extrinsically and intrinsically.
\end{abstract}

Keywords: employee motivation, intrinsic motivation, extrinsic motivation, organizational performance, individual performance, satisfaction, motivation theories. 


\section{Introduction}

Motivation as a psychological concept has great potential to help and initiate development of work performance, workers' overall output and firm's profit maximization. Motivation is an inner force in each of us that drives us towards the determined goal.

The purpose of the study is to find out the factors influencing the motivation in a voluntary environment at the Company of Argeta d.o.o. in Sarajevo. This research aims to descriptively identify the degree of impacts of antecedents and consequences of employee motivation in the selected company. We are going to try discovering methods which will be incentive to motivate workers, so they themselves can find innovative ways to do repetitive and routine-based works, discuss how these elements increase the incentive for future studies on the motivation theories, and how the concepts presented can improve and initiate the future research presented in the article.

The study employs conducting a questionnaire on all available employees working at the Argeta Company in Blazuj - Sarajevo. The employees that participated were both full-time and parttime. They were from different departments, and have been working at the company for at least half a year. The questionnaire consisted of inquiries about personal information, work satisfaction, the degree of satisfaction, and factors of motivation. Data derived from the questionnaire was analyzed and presented in the last part of the paper. The collected data is analyzed descriptively and the results are reported accordingly. Finally, the paper is ended with the conclusion.

\section{Literature review}

\section{Innovation}

Azoulay, Graff and Manso (2011) provided evidence that long-term rewards are much more influential on workers' innovation and motivation rather than short term ones. Petronio and Colacino (2008) suggest the methods for motivating employees in industries. Apart from financial reward system, the authors discuss some of the unconventional additional factors affecting employee motivation. Petronio and Colacino (2008) state that there are three main categories of motivational tools to motivate technical employees:

1. formal structures (written rules and policy conducted in the industry);

2. incentives, rewards and recognition; and

3. informal management techniques

They aim to systematically analyze problematic factors about the motivation of 376 engineers in a work environment, and determine the level and relationship between employees' satisfaction and contribution to innovation. They identified the influencing factors on satisfaction including inadequate reward system; inadequate understanding of engineers' 
expectations; failure to differentiate between professionals and other workers; lack of taskintrinsic motivation; Inadequate managerial competence and knowledge.

\section{Satisfaction}

Furnham, Eracleous and Chamorro-Premuzic (2009) investigated to what extent the employees' personality influences motivation and satisfaction in the workplace by conducting three questionnaires completed by 202 fulltime workers which assessed their work motivation, personality and job satisfaction. They identified that person's job status is the major influence on job satisfaction. They also found that personality and other demographic variables have a lesser degree impact on job satisfaction.

Orpen (1979) explores the effects of job enrichment on employee satisfaction by conducting a field experiment in a federal agency among its clerical employees. They grouped the employees into two randomly assigned them to either an enriched or unenriched conditions. They aim to identify to what extent employees have qualities such as autonomy, skill and performance. After 6 months, they found that the enriched group members were motivated with their job and wanted to learn and be innovative. Their motivation influenced their satisfaction and involvement; while the other group could not progress and become satisfied about their workplace. He suggests that enrichment can cause improvements in behavior and enhance the employees' satisfaction levels.

\section{Organizational culture}

According to Brown (1995), organizational culture is a set of norms, beliefs, principles and ways of behaving and develops the organization's distinctive character. Sadri and Lees (2001) proposes that an effective culture aligned with employees positively influences the firm's performance. They suggest establishing a positive culture for improvement. They also suggest developing communication between managers and workers, if the change of corporate culture is necessary.

\section{Reward System}

Many researchers suggest rewards and recognition in order to increase work motivation and job satisfaction which are directly related to organizational effectiveness (Alhaji \& Fauziah, 2012).

\section{Organizational performance}

Organizational performance/effectiveness is the degree of effectiveness of an organization while achieving the organizational objectives (Malik, Ghafoor \& Naseer, 2011). It is also defined as the fulfilling degrees of organizational objectives by using certain resources without harming its resources and its members and/or society (Thibodeaux \& Favilla, 1996). 
Organizations in the past tended to be unchanging, however, today's businesses need to continuously adjust themselves since technology is constantly changing. Therefore, organizations must employ proper motivational tools in order to improve their performance (Latt, 2008).

According to Allen and Kilmann (2001), the Total Quality Management is a management philosophy in effectively organizing firm's resources in order to meet the demands of the customers. They examined the reward system and its impact on organizational strategy and firm performance and found that higher levels of firm performance were significantly correlated with greater use of TQM practices.

Manzoor (2012) examined the relationship between employees' motivation and organizational effectiveness. He identified that the empowerment and recognition of the employees' effort is the main factor in increasing organizational effectiveness.

\section{Individual performance}

Employee performance is a joint function of ability and motivation, and one of the primary tasks of a manager is motivating employees to perform their best (Moorhead \& Griffin, 1998). Actually, motivation is one of the key issues of modern organizational research (Baron, 1991).

According to Marchant (1999), individual performance is moderated by the personality, values, attitudes and ability of the individual. They also as a group affect their perceptions and motivation, and finally influence individual performance. Furthermore, Marchant (1999) suggested performance appraisal for the employer in order to identify their skills and capabilities and enhance them through training and education.

Chowdhury's (2007), after conducting survey on 105 sales employees in two retail organizations, identified that supervisors who have direct contacts with their subordinates increase the motivation of their subordinates. They also suggested that supervisors with positive motivational behaviors, salespersons' intrinsic motivations and therefore their performance were increased.

\section{Research Model}

Figure 1 presents the assumed relationships of this study's research model. The model is developed by considering the reviewed literature. Moreover, in Table 1, the complete list of model components and their definitions are provided. 


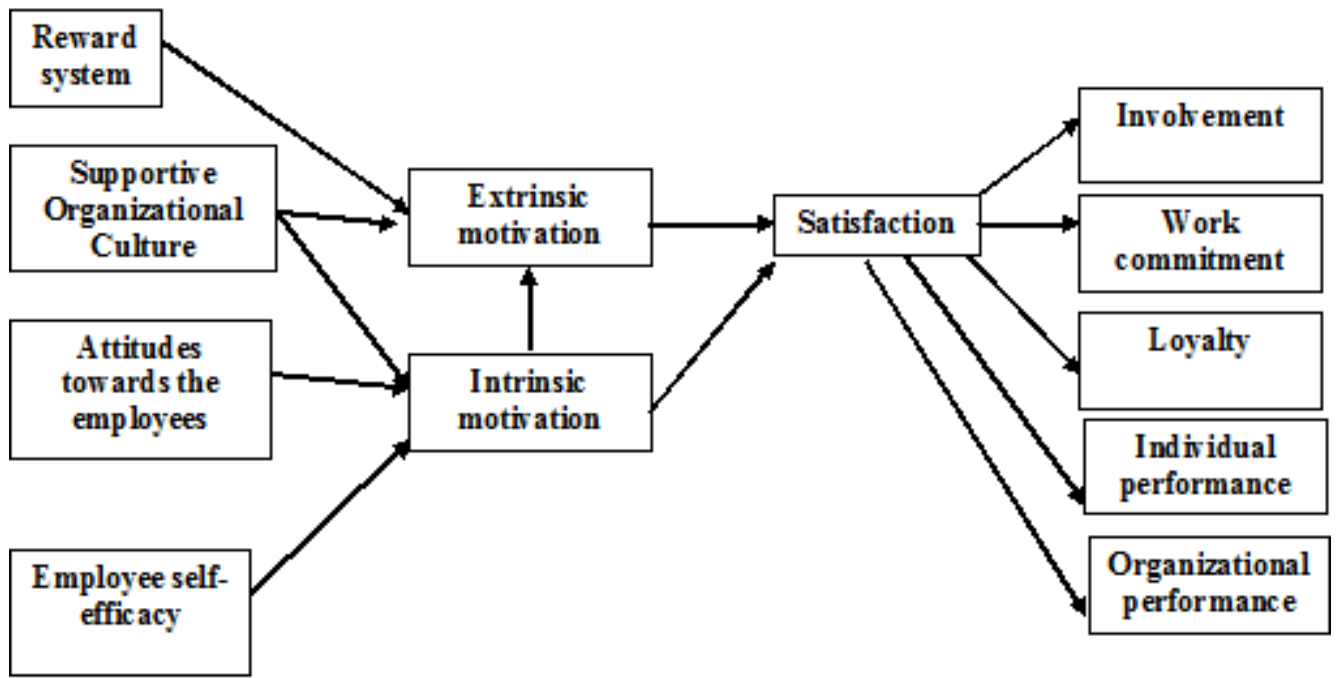

Figure 1. Proposed Research Model

Table 1. Explanation of variables

\begin{tabular}{|c|c|c|}
\hline No & Variable name & Explanation \\
\hline 1 & Reward System & $\begin{array}{l}\text { Reward system is a policy of the company through which } \\
\text { it rewards its employees for their individual performance }\end{array}$ \\
\hline 2 & Extrinsic Motivation & $\begin{array}{l}\text { Extrinsic motivation refers to doing something just } \\
\text { because it leads to a desired outcome, }\end{array}$ \\
\hline 3 & Intrinsic Motivation & $\begin{array}{l}\text { The intrinsic motivation deals with motivation which is } \\
\text { triggered when doing something what seems to be } \\
\text { interesting }\end{array}$ \\
\hline 4 & Employee Self-Efficacy & $\begin{array}{l}\text { Self-efficacy is the measure of employee's own ability to } \\
\text { complete tasks }\end{array}$ \\
\hline 5 & $\begin{array}{l}\text { Attitudes towards the } \\
\text { employee }\end{array}$ & $\begin{array}{l}\text { What is the relationship between managers and } \\
\text { employees }\end{array}$ \\
\hline 6 & \begin{tabular}{|l|} 
Supportive \\
Organizational Culture \\
\end{tabular} & $\begin{array}{l}\text { What is the type of environment and culture the } \\
\text { organization nurtures }\end{array}$ \\
\hline 7 & Satisfaction & $\begin{array}{l}\text { How well is an individual employee satisfied in the } \\
\text { company he works in }\end{array}$ \\
\hline 8 & Involvement & $\begin{array}{l}\text { How well is an individual keen on resolving the problem } \\
\text { and finding a solution for it }\end{array}$ \\
\hline 9 & Work Commitment & $\begin{array}{l}\text { How do employees perceive their task in context of goal } \\
\text { effectiveness }\end{array}$ \\
\hline 10 & Loyalty & How strongly is an employee connected to the company \\
\hline 11 & \begin{tabular}{|l} 
Individual \\
Performance
\end{tabular} & $\begin{array}{l}\text { How well is the individual performing in context of } \\
\text { innovativeness and efficiency }\end{array}$ \\
\hline
\end{tabular}




\section{2}

Organizational
Performance

How well is the organization performing in context of productivity and efficiency

\section{Research Methodology}

\section{Data}

The survey is conducted on the employees in Argeta d.o.o. This company is adequate and appropriate for the research in that it involves its workers in continual and repetitive tasks. This kind of tasks gives a huge range of innovation. Terpstra (1979) argues that the innovation is influenced by motivation. The employees of the company are both full-time and part-time employed, chosen from various departments, and are currently working at the company. Seven point Likert scale is preferred in order to detect the agreements of the respondents on twelve sections through fifty-eight questions. The collected data then inserted into an excel spreadsheet and analyzed descriptively.

\section{Results}

\section{Demographic profile}

The findings on education level suggest that company consists of approximately $64 \%$ of high school graduates working in the company. The administration and office jobs are filled with employees who earned a Master and $\mathrm{PhD}$ degree, $12.7 \%$ and $0.7 \%$ respectively. The company consists of 70 undergraduates holding a Bachelor degree with a $23.3 \%$ of the company.

The respondents of the questionnaire were $70 \%$ male and $30 \%$ female. The company has a very young workforce, with $70 \%$ of the sample respondents being 30 years of age or younger. The most populous workforce in the company is made up of machinists, handlers, general laborers and managers.

\section{Questionnaire Results}

As observed from Table 2, the results slightly suggest that the company has an established financial reward system. There is almost no non-financial reward system observed. The existing weak reward system is observed to be weakly suitable with the characteristics of the employees (Table 2). 
Table 2 Descriptive Results for Reward System

\begin{tabular}{|c|c|c|}
\hline REWARD SYSTEM (4.22) & Mean & $\begin{array}{l}\text { Std. } \\
\text { Deviation }\end{array}$ \\
\hline $\begin{array}{l}\text { There is an established financial reward system in my } \\
\text { organization }\end{array}$ & 4.7 & 1.43 \\
\hline $\begin{array}{l}\text { There is an established non-financial reward system in my } \\
\text { organization }\end{array}$ & 4.1 & 0.778 \\
\hline $\begin{array}{l}\text { The established reward system is suitable with the } \\
\text { characteristics of the employees }\end{array}$ & 4.4 & 1.156 \\
\hline $\begin{array}{l}\text { The established reward system is suitable with the } \\
\text { characteristics of the company }\end{array}$ & 3.91 & 0.955 \\
\hline $\begin{array}{l}\text { The possibility of getting a promotion influences my } \\
\text { performance }\end{array}$ & 4 & 0.931 \\
\hline
\end{tabular}

The findings suggest that the company slightly provide financial reward in order to motivate their employees. However, employees consider themselves slightly negatively motivated when their promotions, salaries, job security and job experience are considered (Table 4).

Table 3 Descriptive Results for Extrinsic Motivation

\begin{tabular}{lll}
\hline \hline EXTRINSIC MOTIVATION (4.02) & Mean & \multicolumn{1}{l}{$\begin{array}{l}\text { Std. } \\
\text { Deviation }\end{array}$} \\
\hline \hline $\begin{array}{l}\text { My company provides financial reward in order to motivate its } \\
\text { employees }\end{array}$ & 4.77 & 1.655 \\
$\begin{array}{l}\text { My company provides promotions in order to motivate its } \\
\text { employers }\end{array}$ & 3.94 & 0.925 \\
$\begin{array}{l}\text { I am satisfied with my salary } \\
\text { I feel secure with my company }\end{array}$ & 3.8 & 0.968 \\
$\begin{array}{l}\text { Gaining proficiency at my job and mastering my position } \\
\text { motivates me to do my best work }\end{array}$ & 3.76 & 0.93 \\
\hline \hline
\end{tabular}

The results reveal that the respondents are motivated by their colleagues' respect. They do not feel that their needs and wants are evaluated by their company. However, they are not happy with the recognition of their efforts and given values for their work by their company. They are slightly negatively agreed that their company shares the profit with them (Table 4). 
Table 4 Descriptive Results for Intrinsic Motivation

\begin{tabular}{lll}
\hline \hline INTRINSIC MOTIVATION (3.97) & Mean & $\begin{array}{l}\text { Std. } \\
\text { Deviation }\end{array}$ \\
\hline \hline My colleagues respect each other & 4.88 & 1.367 \\
My efforts are recognized & 3.88 & 0.932 \\
Employers' needs and wants are evaluated by the company & 4.05 & 0.779 \\
My company shares the profit with us & 3.13 & 1.308 \\
My company gives my work value & 3.91 & 0.899 \\
\hline \hline
\end{tabular}

The respondents report themselves that they have necessary skills to complete their work. They are slightly agreed that they have wishes to develop new ways of doing their job. However, they are neutral that they can easily finish their tasks, are trustworthy related to their work and are not influenced by their personal problems while completing their work (Table 5).

Table 5 Descriptive Results for Employee Self-Efficacy

\begin{tabular}{lcl}
\hline \hline EMPLOYEE SELF-EFFICACY (4.44) & Mean & $\begin{array}{l}\text { Std. } \\
\text { Deviation }\end{array}$ \\
\hline \hline I can easily accomplish my tasks & 4.15 & 0.894 \\
I am not influenced by my personal problems while completing & 4.02 & 1.076 \\
my work & 5.35 & 1.546 \\
I have necessary skills in order to do my work & 3.99 & 0.981 \\
I feel that I am trustworthy related to my work & 4.67 & 1.092 \\
I want to create new ways of doing my job & &
\end{tabular}

The responses for this category of questions slightly identified that the respondents do not feel the company care, the relationship between the managers and the employees, the fair and equitable behavior and the consideration of their needs (Table 6).

Table 6 Descriptive Results for Attitudes towards the Employees

\begin{tabular}{lll}
\hline \hline & Mean & $\begin{array}{l}\text { Std. } \\
\text { Deviation }\end{array}$ \\
\hline \hline I feel that my company cares for its employees & 3.93 & 0.865 \\
My company doesn't discriminate its employees & 3.78 & 0.933 \\
There is a strong relationship between the managers and the & 3.92 & 0.945 \\
employees in my firm & 3.81 & 0.905 \\
My company behaves towards me in a fair and equitable way & 3.8 & 0.956 \\
My company considers the needs of its employees & 3.8 \\
\hline \hline
\end{tabular}


It is observed that the company provides workers a free environment that is also suitable for all types of cultures. However, the findings suggest slight negative results that there are flexible schedules of the employees, easy communication and a variety of support tools and systems for employee tasks (Table 7).

Table 7 Descriptive Results for Supportive Organizational Culture

\begin{tabular}{lll}
\hline \hline SUPPORTIVE ORGANIZATIONAL CULTURE (4.20) & Mean & $\begin{array}{l}\text { Std. } \\
\text { Deviation }\end{array}$ \\
\hline \hline Employee schedules are designed flexible & 3.89 & 0.798 \\
The communication within the company is easy & 3.9 & 0.857 \\
$\begin{array}{l}\text { The workers feel free in their work environment } \\
\text { The environment is suitable for all types of cultures in my }\end{array}$ & 4.7 & 1.659 \\
$\begin{array}{l}\text { company } \\
\text { The employees are supported with a variety of tools and }\end{array}$ & 3.9 & 0.866 \\
systems in their tasks & & \\
\hline \hline
\end{tabular}

The respondents are observed to be slightly satisfied with their company, their duties, offered conditions and incentives of their management. But, they are neutral with their satisfaction of work environment (Table 8).

Table 8 Descriptive Results for Satisfaction

\begin{tabular}{lcl}
\hline \hline & Mean & $\begin{array}{l}\text { Std. } \\
\text { Deviation }\end{array}$ \\
\hline \hline I am quite satisfied with my company & 4.57 & 1.234 \\
I am quite satisfied with my duties in the company & 4.56 & 1.194 \\
I am satisfied with the conditions offered to me by the 4.52 & 1.33 \\
company & & \\
I am satisfied with the work environment in the company & 3.98 & 1.258 \\
I am satisfied with the incentives the management provides & 4.18 & 1.108 \\
for us & & \\
\hline \hline
\end{tabular}

The employees fairly feel themselves as part of the company and as part of a successful team. They furthermore are slightly agreed that the company will fail, if they don't finish their work (Table 9). 
Table 9 Descriptive Results for Involvement

\begin{tabular}{|c|c|c|}
\hline INVOLVEMENT (4.27) & Mean & $\begin{array}{l}\text { Std. } \\
\text { Deviation }\end{array}$ \\
\hline I feel as a part of my company & 4.23 & 1.22 \\
\hline $\begin{array}{l}\text { If I don't accomplish my duty, I am scared my company would } \\
\text { fail }\end{array}$ & 4.21 & 1.223 \\
\hline $\begin{array}{l}\text { Management seems to care about employees on both } \\
\text { professional and personal levels }\end{array}$ & 4.4 & 1.215 \\
\hline I see myself as a part of big and successful team. & 4.24 & 1.177 \\
\hline
\end{tabular}

The employees seem to be slightly agreed that their loss is dependent upon the company loss. However, they slightly do not always seem to consider company benefits and the ways of company success. Furthermore, they have slightly negative on that they do not go home without finishing their work. Finally, they are negative on that it is not matter if their company pays less (Table 10).

Table 10 Descriptive Results for Work Commitment

\begin{tabular}{lll}
\hline \hline WORK COMMITMENT (3.77) & Mean & $\begin{array}{l}\text { Std. } \\
\text { Deviation }\end{array}$ \\
\hline \hline If my company loses, I will loose & 4.32 & 0.807 \\
I always consider the benefits for my company & 3.84 & 0.89 \\
I always think of the ways of how my company can succeed & 3.73 & 0.891 \\
It does not matter, if my company pays me less & 3.16 & 1.178 \\
Sometimes I don't go home in time, if I don't finish my work & 3.78 & 0.895 \\
\hline \hline
\end{tabular}

According to the results, it is observed that Loyalty related questions are slightly disagreed by the respondents. The findings suggest that employees can quit their company and work for another company in the future. They furthermore do not consider that their existing company deserves the loyalty of its employees (Table 11).

Table 11 Descriptive Results for Loyalty

\begin{tabular}{lcl}
\hline \hline LOYALTY (3.88) & Mean & $\begin{array}{l}\text { Std. } \\
\text { Deviation }\end{array}$ \\
\hline \hline I don't think that I can work for another company & 3.84 & 0.904 \\
I will never quit my company & 3.85 & 0.914 \\
The company deserves the loyalty of its employees & 3.88 & 0.908 \\
The company provides the necessary tools and training for & 3.94 & 0.937 \\
employees to perform their jobs well & & \\
\hline \hline
\end{tabular}


The findings reveal that individual performance is rated well by the employees except their contribution to work. They believe that they improved their creativity and innovativeness and the relationships with their boss and managers and they can easily complete their tasks (Table 12).

Table 12 Descriptive Results for Individual Performance

\begin{tabular}{|c|c|c|}
\hline INDIVIDUAL PERFORMANCE (5.05) & Mean & $\begin{array}{l}\text { Std. } \\
\text { Deviation }\end{array}$ \\
\hline I enhanced my creativity and innovativeness & 5.04 & 1.332 \\
\hline I can easily complete my tasks & 5.07 & 1.324 \\
\hline $\begin{array}{l}\text { I am able to complete the project using methods that have } \\
\text { been successful in the past when used on similar projects }\end{array}$ & 5.53 & 1.286 \\
\hline I have better relationships with my boss, managers & 5.27 & 1.135 \\
\hline My contribution to work has increased & 4.32 & 0.73 \\
\hline
\end{tabular}

The findings suggest a neutral stance of respondents when it comes to organizational performance. They slightly agree that organizational environment has become more motivating (Table 13).

Table 13 Descriptive Results for Organizational Performance

\begin{tabular}{|c|c|c|}
\hline ORGANIZATIONAL PERFORMANCE (4.01) & Mean & $\begin{array}{l}\text { Std. } \\
\text { Deviation }\end{array}$ \\
\hline My organization has a better motivational system & 3.92 & 0.856 \\
\hline $\begin{array}{l}\text { Communication at my company has become highly effective } \\
\text { and makes me feel like an integral part of the team }\end{array}$ & 3.87 & 0.858 \\
\hline Organizational environment has become more motivating & 4.38 & 1.334 \\
\hline $\begin{array}{l}\text { Seeing the positive impact my work has on the company and } \\
\text { others outside the company motivates me to do my best work }\end{array}$ & 3.84 & 0.801 \\
\hline $\begin{array}{l}\text { Management has become more aware and shown a genuine } \\
\text { interest in motivating employees and assessing their } \\
\text { performance }\end{array}$ & 4.04 & 0.926 \\
\hline
\end{tabular}

\section{Discussion}

This research aims to descriptively identify the degree of impacts of antecedents and consequences of employee motivation in the selected company. It has become successful in that it could reach its objective. According to the results, it can be concluded that the results of descriptive analysis could not provide a high agreement level of respondents for the questions asked. The responses are accumulated generally around neutral except with high negative agreement on the attitudes towards employees and positive agreement on the individual 
performance. According to the results, there is a poorly established reward system and organizational culture in the company. Furthermore, attitudes towards the employees are negative. Therefore, there seems almost no support from the individual's external environment within the company in order to increase his/her motivation. On the other hand, the individuals are rated themselves as slightly self-efficient and effective. So, in general there exist very weak from both external and internal environment for an individual to increase the motivation. Accordingly, it is observed that both types of motivation do not exist. They moreover seem to be slightly satisfied and involved with their company. However, they are observed to be not committed and loyal to their work. Finally, they seem to gain positive benefits while their company does not progress.

Khan et al. (2010) found that extrinsic rewards such as recognition of the others and work motivation have a statistical significant relationship. They found out that recognition was a major non-financial factor in enhancing workers' motivation. Our findings suggest the same observation but beside the non-financial rewards, the respondents were not keen on working for the lower pay which suggests that the respondents were primarily influenced by the salary they receive for their efforts.

Petronio and Colacino (2008) suggest that lack of task-intrinsic motivation can lower the motivation of the employees. It is observed that employees have adequate skills for their job positions, but lack a challenging task that would enhance their motivation. They need to be encouraged and not occupied with boring routines. However the problem is that communication in the company between the manager and employees is not established accordingly, and the encouragement may lack for this reason.

Table 14 Descriptive Results for Overall Evaluation

\begin{tabular}{ll}
\hline \hline MEASURES & MEAN \\
\hline \hline REWARD SYSTEM & 4.22 \\
EXTRINSIC MOTIVATION & 4.02 \\
INTRINSIC MOTIVATION & 3.97 \\
EMPLOYEE SELF-EFFICACY & 4.44 \\
ATTITUDES TOWARDS THE EMPLOYEES & 3.38 \\
SUPPORTIVE ORGANIZATIONAL CULTURE & 4.2 \\
SATISFACTION & 4.36 \\
INVOLVEMENT & 4.27 \\
WORK COMMITMENT & 3.77 \\
LOYALTY & 3.88 \\
INDIVIDUAL PERFORMANCE & 5.05 \\
ORGANIZATIONAL PERFORMANCE & 4.01 \\
\hline \hline TOTAL & $\mathbf{4 . 1 3}$
\end{tabular}


Cropanzano, Bowen and Gililand (2007) suggest that different employees have different needs and different motivators. The findings of this study suggest that while most people find financial bonuses as the primary determinants of motivation, others prefer non-financial rewards such as recognition from manager, respect from colleagues and empowerment from organization.

According to Moser (1997), when there is a lack of job satisfaction the person wants to quit that job similar to the results of this study. Moser (1997) also suggests the importance of job satisfaction on organizational commitment. The reasonable satisfaction level in the results of this study may be the reason of poor level of the employees' involvement. Organizational performance and commitment unlike individual performance were very low rated. The reason for this could be in the demographics of the company. The company may have too few competent managers, or the manager's leadership style may be inappropriate for the employees. It may be suggested that the company should employ competent managers to lead the company and increase organizational effectiveness.

\section{Conclusion}

This research identifies the degree of impacts of antecedents and consequences of employee motivation in a selected Bosnian company. The results identified that the responses are not highly positive for the questions being asked. Beside the negative influence of attitudes towards employees, the influencing factors of employee motivation are found to be poor. Therefore, the employees have no motivation and therefore their satisfaction, involvement, loyalty levels are very low. Furthermore, it is believed by the respondents that the company cannot reach a desired level of benefits. However, employees are found to have gained some individual benefits.

Based on the study results, this study recommends improving manager-employees relations and conducting contingent theory's test of favorability. Companies should especially change the attitudes towards their employees and arrange their reward system, enhance their organizational culture support and increase the self-efficacy of their employees. Therefore, it can be expected that their motivation levels could be increased. If their motivation is increased, their satisfaction and accordingly involvement, commitment, loyalty, organizational and individual benefits are also enhanced.

This research is limited in that it only discovers the employees of a specific company. Future research can involve more companies and different types of companies.

\section{Corresponding Author}

\section{Muhammed Kürşad Özlen}

Faculty of Economics and Administrative Sciences, Ishik University/Erbil, Iraq

E-mail: kursadozlen@yahoo.com 


\section{References}

Alhaji, I. A. and Fauziah, W. Y. (2012). Does motivational factor influence organizational commitment and effectiveness? A review of literature. Journal of Business Management and Economics, 3(1), 001-009.

Allen, R.S. \& Kilmann, R.H. (2001). The role of the reward system for a total quality management based strategy. Journal of Organizational Change Management, 14(2).

Argeta (2010). Argeta.eu, History. Retrieved on May, 18 from http://www.argeta.eu/argetas_story/history?aid=51

Azoulay, P., Graff Z. J., \& Manso, G. (2011). Incentives and creativity: Evidence from the academic life sciences. Rand Journal of Economic, Rand Corporation. 42 (3), 527-554.

Brown, A. (1995). Organisational Culture, Pitman Publishing, London.

Chowdhury, M. S. (2007). Enhancing motivation and work performance of the salespeople: the impact of supervisors' behavior. African Journal of Business Management, 1(9), 238-243.

Cropanzano, R., Bowen, D.E. \& Gilliland S.W. (2007). The management of organizational justice. Academy of Management Perspectives.

Furnham, A., Eracleous, A. \& Chamorro-Premuzic, T. (2009). Personality, motivation and job satisfaction: Hertzberg meets the Big Five., Journal of Managerial Psychology, 24(8), 765 - 779.

Khan, K. U., Farooq, S. U., \& Ullah, M. I. (2010). The Relationship between Rewards and Employee Motivation in Commercial Banks of Pakistan. Journal of International Studies, 1 (14), 37-54.

Latt, K.A. (2008). Motivating people on the way towards organizational performance. Victoria University (Australia).

Malik, M. E., Ghafoor, M. M., \& Naseer, S., (2011). Organizational Effectiveness: A Case Study of Telecommunication and Banking Sector of Pakistan. Far East Journal of Psychology and Business, 2 (1), 37-48.

Manzoor, Q.A. (2012). Impact of Employees Motivation on Organizational Effectiveness. European Journal of Business and Management. 3(3).

Marchant, T. (1999). Strategies for improving individual performance and job satisfaction at Meadowvale Health. 
Moorhead, G., \& Griffin, R. W. 1998. Organizational Behavior: Managing people and organizations (5th ed.). Boston, MA: Houghton Mifflin.

Moser, K. (1997). Commitment in organizations. Psychologies 41 (4), 160-170.

Orpen, C. (1979). The Effects of Job Enrichment on Employee Satisfaction, Motivation, Involvement, and Performance: A Field Experiment. Human Relations March 1979., 32 (3), 189217

Petronio, A. \& Colacino, P. (2008). Motivation Strategies for knowledge workers: evidences and challenges. Journal of technology management \& innovation 3(3). 21-32.

Sadri, G., \& Lees, B. (2001). Developing corporate culture as a competitive advantage, Journal of Management Development, 20 (10), 853 - 859.

Terpstra, D. E. (1979). Theories of motivation: borrowing the best. Personnel Journal, 58. 376.

Thibodeaux, M.S. \& Favilla, E. (1996). Organizational effectiveness and commitment through strategic management. Industrial Management \& Data Systems, 96 (5), 21 - 25. 


\section{Appendix}

Survey on the Study of Motivation

Description of rating scales:

\begin{tabular}{|c|c|c|}
\hline \multirow{2}{*}{$\begin{array}{l}\text { Number } \\
1\end{array}$} & Value & Meaning Assigned \\
\hline & Strongly disagree & You totally disagree with the statement \\
\hline 2 & Disagree & You believe that statement is not true to some extent \\
\hline 3 & Slightly disagree & You are partially disagreed with the statement \\
\hline 4 & Neutral & You are finding statement as not influential \\
\hline 5 & Slightly agree & You are partially agreed with the statement \\
\hline 6 & Agree & You believe that statement is true to some extent \\
\hline 7 & Strongly agree & You are completely agreed with the statement \\
\hline
\end{tabular}

Note: Please fill the following information about you and your organization

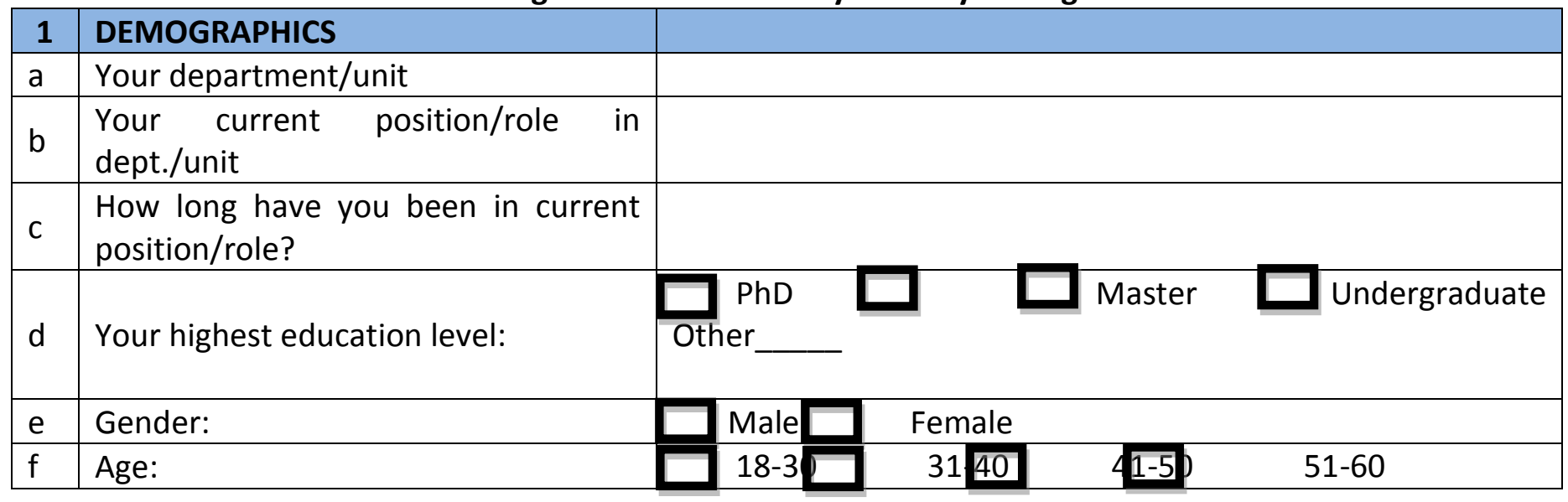

\begin{tabular}{|l|l|l|l|l|l|l|l|l|}
\hline & REWARD SYSTEM & 1 & 2 & 3 & 4 & 5 & 6 & 7 \\
\hline 2 & $\begin{array}{l}\text { The established reward system is suitable with the } \\
\text { characteristics of the employees }\end{array}$ & $\begin{array}{l}\text { The established reward system is suitable with the } \\
\text { characteristics of the company }\end{array}$ & & & & & & \\
\hline 3 & $\begin{array}{l}\text { The possibility of getting a promotion influences my } \\
\text { performance }\end{array}$ & & & & & \\
\hline
\end{tabular}

\begin{tabular}{|l|l|l|l|l|l|l|l|l|} 
& EXTRINSIC MOTIVATION & 1 & 2 & 3 & 4 & 5 & 6 & 7 \\
\hline 1 & I am satisfied with my salary & & & & & & & \\
\hline 2 & I feel secure with my company & & & & & & & \\
\hline 3 & $\begin{array}{l}\text { Gaining proficiency at my job and mastering my position } \\
\text { motivates me to do my best work. }\end{array}$ & & & & & & \\
\hline
\end{tabular}




\begin{tabular}{|l|l|l|l|l|l|l|l|l|}
\hline & INTRINSIC MOTIVATION & 1 & 2 & 3 & 4 & 5 & 6 & 7 \\
\hline 1 & My efforts are recognized are evaluated by the & & & & & & \\
\hline 2 & $\begin{array}{l}\text { Employers' needs and wants ared } \\
\text { company }\end{array}$ & & & & & & & \\
\hline 3 & My company gives my work value
\end{tabular}

\begin{tabular}{|l|l|l|l|l|l|l|l|l|}
\hline & EMPLOYEE SELF-EFFICACY & 1 & 2 & 3 & 4 & 5 & 6 & 7 \\
\hline 1 & I can easily accomplish my tasks & & & & & & & \\
\hline
\end{tabular}

\begin{tabular}{|l|l|l|l|l|l|l|l|l|} 
& ATTITUDES TOWARDS THE EMPLOYEES & 1 & 2 & 3 & 4 & 5 & 6 & 7 \\
\hline 1 & My company doesn't discriminate its employees & & & & & & & \\
\hline 2 & $\begin{array}{l}\text { My company behaves towards me in a fair and } \\
\text { equitable way }\end{array}$ & & & & & & \\
\hline
\end{tabular}

\begin{tabular}{|l|l|l|l|l|l|l|l|l|} 
& SUPPORTIVE ORGANIZATIONAL CULTURE & 1 & 2 & 3 & 4 & 5 & 6 & 7 \\
\hline 1 & Employee schedules are designed flexible & & & & & & & \\
\hline 2 & The communication within the company is easy & & & & & & & \\
\hline 3 & $\begin{array}{l}\text { The employees are supported with a variety of tools and } \\
\text { systems in their tasks }\end{array}$ & & & & & & \\
\hline
\end{tabular}

\begin{tabular}{|l|l|l|l|l|l|l|l|l|}
\hline & SATISFACTION & 1 & 2 & 3 & 4 & 5 & 6 & 7 \\
\hline 1 & I am quite satisfied with my company & & & & & & & \\
\hline 2 & I am satisfied with the work environment in the company & & & & & & & \\
\hline
\end{tabular}

\begin{tabular}{|l|l|l|l|l|l|l|l|l|} 
& INVOLVEMENT & 1 & 2 & 3 & 4 & 5 & 6 & 7 \\
\hline 1 & $\begin{array}{l}\text { If I don't accomplish my duty, I am scared my company } \\
\text { would fail }\end{array}$ & & & & & & \\
\hline 2 & I see myself as a part of big and successful team. & & & & & & & \\
\hline
\end{tabular}

\begin{tabular}{|l|l|l|l|l|l|l|l|l|} 
& WORK COMMITMENT & 1 & 2 & 3 & 4 & 5 & 6 & 7 \\
\hline 1 & I always think of the ways how my company can succeed & & & & & & & \\
\hline 2 & It does not matter if my company pays me less & & & & & & & \\
\hline 3 & $\begin{array}{l}\text { Sometimes I don't go home in time, if I don't finish my } \\
\text { work }\end{array}$ & & & & & & \\
\hline
\end{tabular}

\begin{tabular}{|l|l|l|l|l|l|l|l|l|}
\hline & LOYALTY & 1 & 2 & 3 & 4 & 5 & 6 & 7 \\
\hline 1 & I don't think that I can work for another company & & & & & & & \\
\hline 2 & I will never quit my company & & & & & & & \\
\hline 3 & The company deserves the loyalty of its employees & & & & & & & \\
\hline 4 & $\begin{array}{l}\text { The company provide the necessary tools and training } \\
\text { for employees to perform their jobs well }\end{array}$ & & & & & & \\
\hline
\end{tabular}




\begin{tabular}{|l|l|l|l|l|l|l|l|l|}
\hline & INDIVIDUAL PERFORMANCE & 1 & 2 & 3 & 4 & 5 & 6 & 7 \\
\hline 1 & I enhanced my creativity and innovativeness & & & & & & & \\
\hline 2 & I can easily complete my tasks & & & & & & & \\
\hline 3 & $\begin{array}{l}\text { I am able to complete the project using methods that } \\
\text { have been successful in the past when used on similar } \\
\text { projects }\end{array}$ & & & & & & \\
\hline 4 & I have better relationships with my boss, managers & & & & & & & \\
\hline
\end{tabular}

\begin{tabular}{|l|l|l|l|l|l|l|l|l|} 
& ORGANIZATIONAL PERFORMANCE & 1 & 2 & 3 & 4 & 5 & 6 & 7 \\
\hline 1 & My organization has a better motivational system & & & & & & & \\
\hline 2 & $\begin{array}{l}\text { Communication at my company has become highly } \\
\text { effective and makes me feel like an integral part of the } \\
\text { team }\end{array}$ & $\begin{array}{l}\text { Organizational environment has become more } \\
\text { motivating }\end{array}$ & & & & & & \\
\hline
\end{tabular}

